University of Nebraska - Lincoln

DigitalCommons@University of Nebraska - Lincoln

$5-1990$

\title{
Bower Size and Male Reproductive Success in a Cichlid Fish Lek
}

Kenneth R. McKaye

Appalachian Environmental Laboratory, Frostburg, Maryland

Svata M. Louda

University of Nebraska - Lincoln, slouda1@unl.edu

Jay R. Stauffer, Jr.

Pennsylvania State University

Follow this and additional works at: https://digitalcommons.unl.edu/bioscifacpub

Part of the Life Sciences Commons

McKaye, Kenneth R.; Louda, Svata M.; and Stauffer, Jr., Jay R., "Bower Size and Male Reproductive Success in a Cichlid Fish Lek" (1990). Faculty Publications in the Biological Sciences. 56.

https://digitalcommons.unl.edu/bioscifacpub/56

This Article is brought to you for free and open access by the Papers in the Biological Sciences at DigitalCommons@University of Nebraska - Lincoln. It has been accepted for inclusion in Faculty Publications in the Biological Sciences by an authorized administrator of DigitalCommons@University of Nebraska - Lincoln. 


\title{
BOWER SIZE AND MALE REPRODUCTIVE SUCCESS IN A CICHLID FISH LEK
}

\author{
Kenneth R. McKaye, Svaťa M. Louda, and Jay R. Stauffer, Jr. \\ University of Maryland, Center for Environmental and Estuarine Studies, Appalachian \\ Environmental Laboratory, Frostburg, Maryland 21532; School of Biological Sciences, University \\ of Nebraska, Lincoln, Nebraska 68588; School of Forest Resources, Pennsylvania State \\ University, University Park, Pennsylvania 16802
}

Submitted August 26, 1988; Revised March 1, 1989; Accepted July 7, 1989

Sexual selection may be a major factor in the proliferation of polygamous species (Lande 1981). When males provide no resources or parental care and females have numerous males from which to choose, "extravagant" male secondary characteristics may result solely from sexual selection (Darwin 1871; Fisher 1930; Lande 1981). Dominey (1984) argued that such "runaway" sexual selection was the driving mechanism behind the explosive speciation of the polygamous cichlid fishes in the Great Lakes of Africa. However, the few studies examining cichlid mate selection in situ have concentrated primarily on species engaging in biparental care of the young (Perrone 1978; Neil 1984; McKaye 1986). Although reproductive behavior has long been hypothesized to be important in the ecology and evolution of cichlids (Lowe-McConnell 1959; Fryer and Iles 1972; McKaye 1984), factors influencing female choice and the relative reproductive success of males are poorly known for most field populations.

Several hundred cichlid species inhabit the sandy and weedy environments of Lake Malawi (McKaye 1984; McKaye and Gray 1984; McKaye, in press) and have lek-based breeding systems (Fryer and Iles 1972; McKaye 1983, 1984) with display sites that vary dramatically among species. Leks are defined as aggregates of adult males that do not contribute resources or parental care; females visit only to have their eggs fertilized (see Bradbury and Gibson 1983; Borgia 1985). During ecological studies of this sand-dwelling community, we have discovered 10 basic sand forms built by cichlid fishes in the Cape Maclear region of Lake Malawi (McKaye 1984, in press). They range in size from giant craters $3 \mathrm{~m}$ in diameter (McKaye and Stauffer 1988) to small depressions in the sand and include "sand castles" (Bass 1988, see pp. 152-153 for photograph) with base diameters of more than $1 \mathrm{~m}$ (McKaye 1984). Because display sites vary significantly in size and shape, an experienced observer can distinguish among sibling species on the basis of the display site alone (McKaye 1984; McKaye and Stauffer, MS). Relationships among species presumed from the similarity of display sites have recently been 
confirmed by electrophoretic analyses of tissue samples (McKaye, J. Howard, Stauffer, R. Morgan, and F. Feresu, MS).

The term "nest" has been used to describe these display sites (Fryer and Iles 1972; Keenleyside 1979; McKaye 1983, 1984; McKaye and Stauffer 1988). However, we now prefer to use the term "bower" as found in the ornithological literature (Collias and Collias 1983; Borgia 1985; Borgia et al. 1985) to characterize these sites of courtship and spawning. They are constructed independently of the need to care for eggs and young (McKaye 1984). The female deposits eggs in the bower (nest) and then immediately picks them up in her mouth, where they are fertilized. Eggs are then brooded solely in the mouth of the female. Males engage in no parental care. The form and function of the arenas and the display sites, or bowers, are clearly analogous to bird leks (Fryer and Iles 1972; McKaye 1983, 1984). Some arenas are relatively small $(30 \mathrm{~m} \times 20 \mathrm{~m})$; others may extend for several kilometers.

Bower size could be a critical characteristic in determining female choice and relative male success for the species Cyrtocara eucinostomus (McKaye 1983). Therefore, we examined the dynamics of female mate choice in this species, one of the zooplankton-feeding fishes, or "utaka," from Lake Malawi, which Dominey $(1984$, p. 236) specifically discussed in support of the sexual-selection hypothesis of speciation.

We tested two hypotheses: (1) male reproductive success improves as bower size increases; and (2) after a disturbance, density, dispersion, and sizes of bowers in this arena rapidly return to predisturbance conditions. We directly observed the behavior of $C$. eucinostomus males above bowers and experimentally removed bowers in order to answer five subsidiary questions. Did males above large bowers attract more females? Were larger bowers defended more aggressively, or more persistently, than smaller bowers? Were new bowers rebuilt in the same place as old bowers or were they established de novo? Were any bower characteristics species-specific? And finally, were patterns of bower initiation and construction consistent spatially within the arena? Answers to these questions would provide a basis for further examining the role sexual selection may have played in the explosive cichlid radiations common to the Great Lakes of Africa (Dominey 1984).

\section{METHODS}

\section{Courtship and Aggressive Behavior in Relation to Bower Size}

Using scuba, we observed the behavior of 43 pairs of Cyrtocara eucinostomus males for 10-min periods. One of each pair was above a "tall" bower (mean height, $24.9 \mathrm{~cm}$ ); the other was above a "short" bower (mean height, $10.4 \mathrm{~cm}$ ). We measured actual bower heights after each observation period (fig. 1). We recorded courtship bouts (defined as a single unit of all courtship displays of a male to a female), attacks on conspecific breeding males, attacks on conspecifics with nonbreeding coloration, and attacks on heterospecifics. We estimated male reproductive success by counting both the number of times a female entered the 


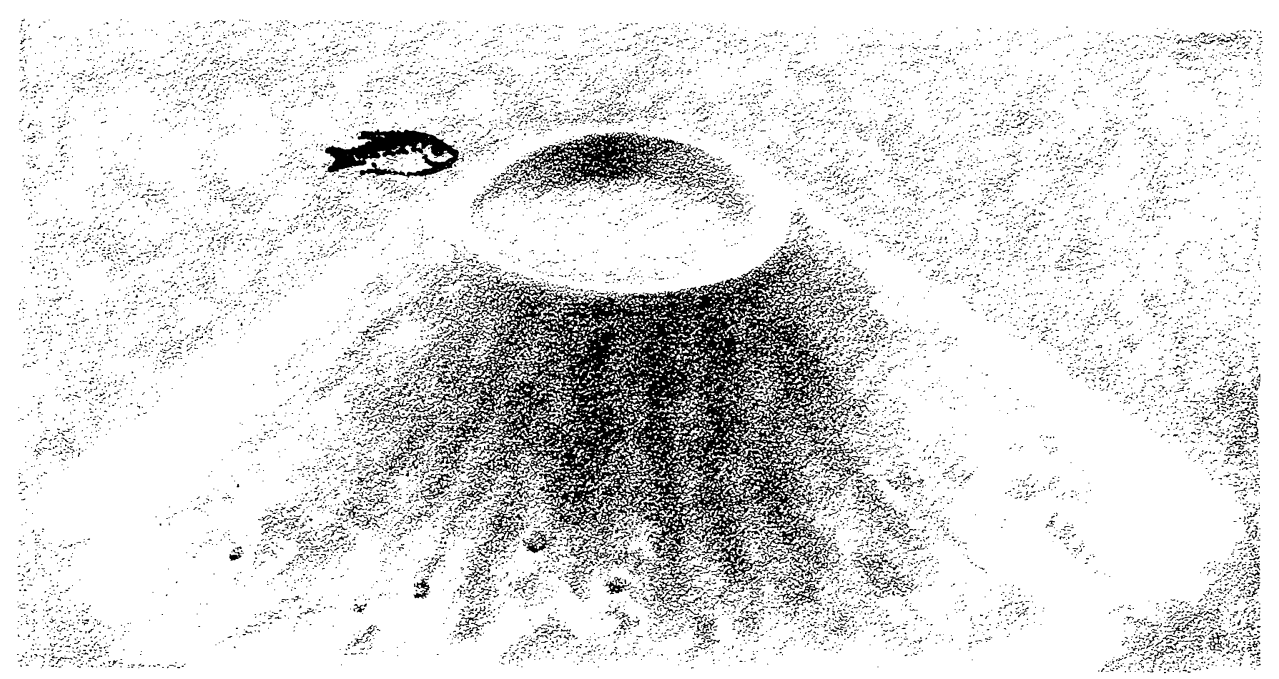

Fig. 1.-Bower of Cyrtocara eucinostomus. Length of fish is $100 \mathrm{~mm}$.

bower and whether a female actually circled with the male above his bower. Entry and circling correlate directly with the number of eggs laid in the bower (McKaye 1983). Of the 43 pairs studied, 26 pairs had bowers at water depths greater than 8.0 $\mathrm{m}$, and 17 had bowers at depths between 6.0 and $8.0 \mathrm{~m}$. We tested for significant differences (Wilcoxon paired-samples test, $P<0.05$ ) in the number of attacks, courtships, and times females entered the bowers of males with large or small bowers.

\section{Bower Removal}

We removed bowers in Lake Malawi to determine the importance of bower form in female choice (McKaye 1983; Dominey 1984). We expected males to rebuild bowers if bower size is important to reproductive success. To test this prediction, we manipulated bower density on four of eight square, $100-\mathrm{m}^{2}$ plots. Four plots were at a 7-m water depth, and four were at a 10-m depth; all plots were separated by $50 \mathrm{~m}$. Two treatments were assigned to plots: control or bower removal. Before any manipulation of the removal plots, we measured base diameter, height, and top diameter (fig. 1) and mapped the locations of all bowers present in each plot. We then leveled all of the bowers on the experimental removal plots. Two divers smoothed the sand with boards. We could see no evidence of the earlier bowers afterward. On control plots, the divers swam around bowers and disturbed the areas between them but did not manipulate any bowers.

As a new bower appeared, we placed a stake $0.7 \mathrm{~m}$ to the north of it and assigned an identification number. Over the next 16 days, we measured the size of each marked bower every day for 3 days, every other day for another 7 days, and then every third day. When a bower was abandoned, we noted the identification number and its size rank among all other bowers still in use at the last census. At 
the end of the experiment, we mapped locations of all bowers established during the experiment.

Additionally, we recorded bower occupancy on our control plots between 8 and 10:30 A.M. and between 3:30 and 6 P.M. on five dates. These data document the proportion of males occupying bowers in relation to the size of the bowers.

\section{Temporal and Depth Distribution of Bowers}

We counted C. eucinostomus bowers once every $2 \mathrm{wk}$ at six sites spaced along the 4-km beach at Cape Maclear (see maps in McKaye and Stauffer 1988, figs. 1, 2). We censused $10200-\mathrm{m}^{2}$ transects $(50 \mathrm{~m} \times 4 \mathrm{~m})$ at 10 evenly spaced depths between 0 and $15 \mathrm{~m}$. The counts were made from August 1981 to November 1982 and from December 1983 to April 1984. We also made $4025-\mathrm{m}^{2}$ transects at night (at 7 P.M. and 1 and 4 A.M.). They were examined at depths of 3-14 $\mathrm{m}$ at 3-m intervals. All C. eucinostomus individuals within $2 \mathrm{~m}$ of either side of a $25-\mathrm{m}$ transect were counted.

\section{RESULTS}

\section{Courtship and Aggressive Behavior in Relation to Bower Size}

Courtship.-If bower size is important in attracting females, then males above taller bowers should have more courtship opportunities. We found that males above tall bowers were more successful in all measures of courtship than were males above short bowers (fig. 2) because they courted more frequently (Wilcoxon test, $P<0.01, N=43)$, enticed more females to enter their bowers $(P<$ $0.01, N=43)$, and circled more with females $(P<0.05, N=43)$.

Attacks. - If bower size is important to male reproductive success, then males above tall bowers are predicted to exhibit more-aggressive interactions toward conspecific competitors than those above small bowers. This aggression could arise from the need of the male to defend the more-valuable site and/or the tendency for other males, both those in breeding dress and "sneakers" that mimic females (McKaye 1983; Dominey 1984), to try to usurp it. Our results are consistent with this prediction. Attacks upon conspecific males, both with blue breeding color and with nonbreeding silver color, were significantly more frequent by males above tall bowers than by those above short bowers (fig. 3; Wilcoxon test, $P<$ 0.01 ). However, we found no significant differences between males above tall and short bowers in the number of attacks upon heterospecific cichlids (fig. $3 ; P>$ 0.05).

Bower occupancy. - If bower height is important to reproductive success, then males should be less likely to leave tall bowers than short bowers to forage. In the afternoon, most of the fish abandon their bowers to feed (McKaye 1983), but this abandonment was not randomly related to bower size. Of the bowers shorter than $8 \mathrm{~cm}, 25 \%$ were occupied from 3:30 to 6 P.M. at both the shallow and the deep plots (table 1). Approximately $90 \%$ of the bowers taller than $15 \mathrm{~cm}$ were occupied during the same time. We found no difference between deep and shallow plots for these tall and short size classes. However, occupancy rate differed significantly between deep and shallow bowers in the size class of 8.1-15.0 $\mathrm{cm}\left(\chi^{2}=7.3, P<\right.$ $0.01)$. The majority (56\%) of the shallow bowers in this size range were occupied; 


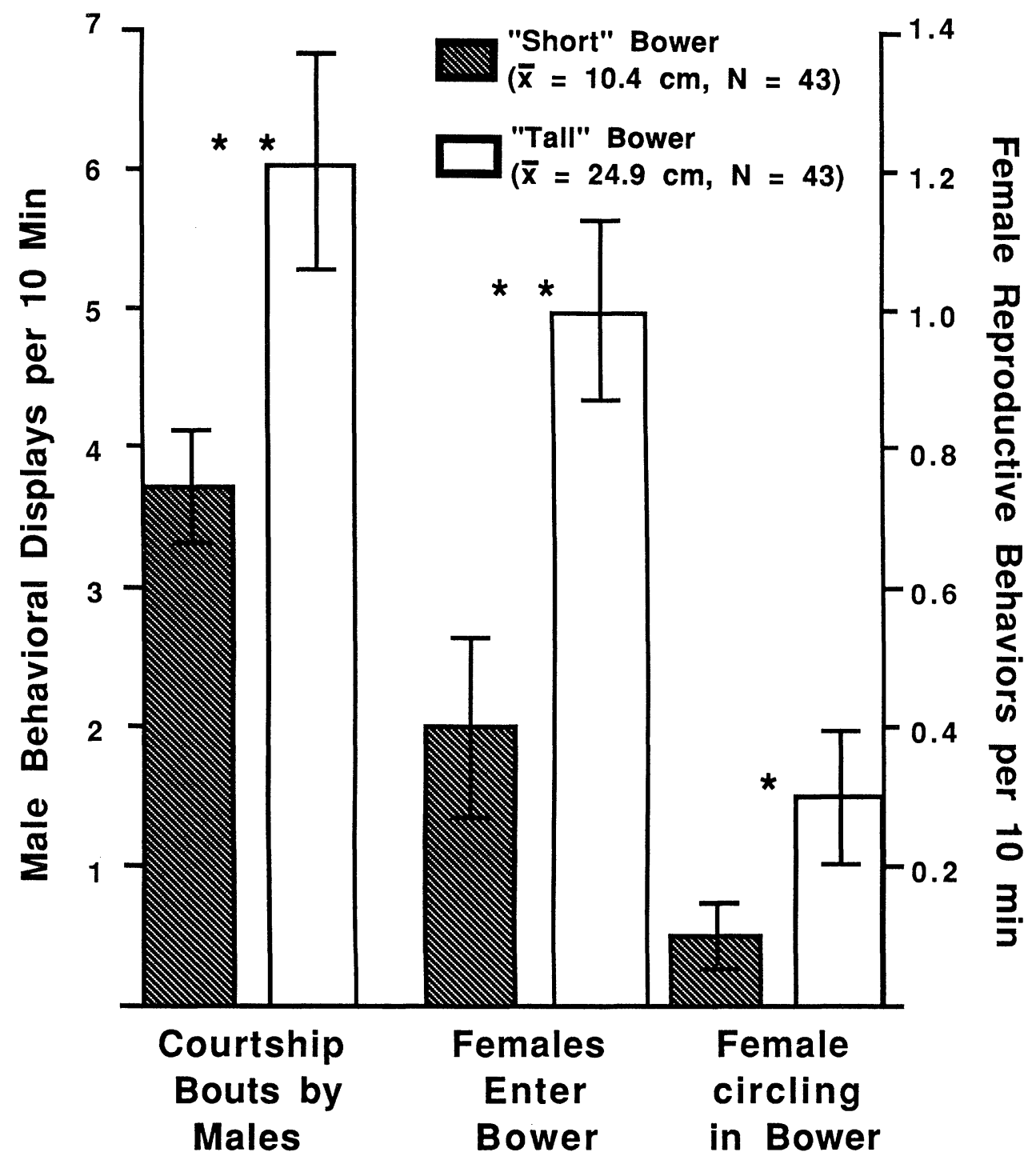

FIG. 2.-Behavior of males and females above paired bowers. Bars, Means; vertical lines, one standard error on either side of the mean. All differences between behavior above the tall bower versus the small bower were significant (Wilcoxon test): ${ }^{*} P<0.05$; ${ }^{* *} P<0.01$.

only $29 \%$ of the deeper bowers were occupied. Regardless of size, virtually all bowers were occupied in the morning, substantiating previously reported patterns of behavior (McKaye 1983).

\section{Bower Reestablishment and Construction Rates}

If the size of the bower is important to male reproductive success, then removed bowers should be rebuilt rapidly in order to attract females. Our experimental results confirmed this prediction. New bowers were initiated within $24 \mathrm{~h}$ in 


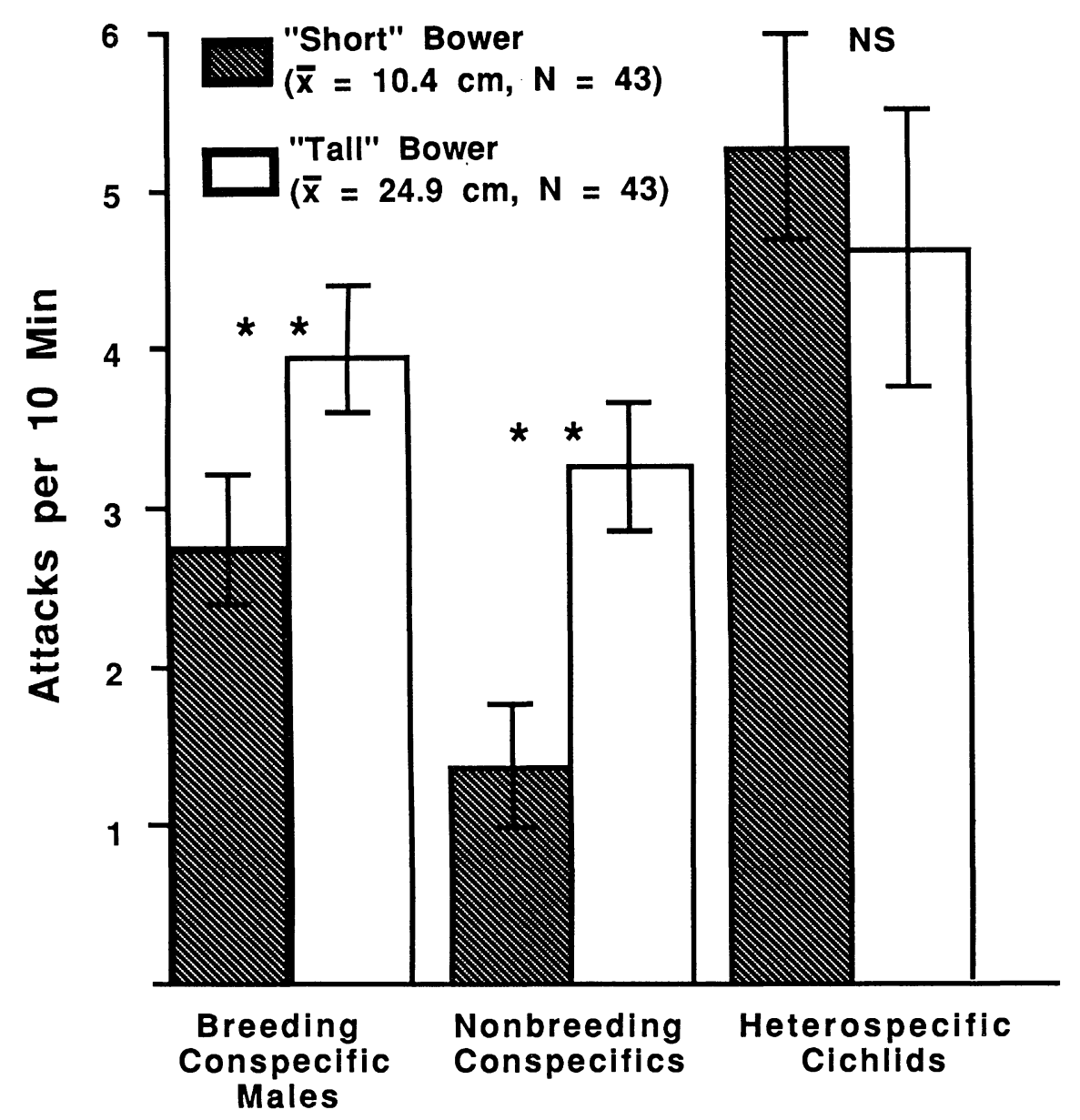

Targets of Attack

FIG. 3.-Aggressive behavior of males above paired bowers. Bars, Means; vertical lines, one standard error on either side of the mean. Differences between behavior above the tall bower versus the small bower were significant (Wilcoxon test): ${ }^{* *} P<0.01$; NS, $P>0.05$.

all four of the removal plots. None of the new bowers was started in precisely the same location as the earlier bowers.

Control and experimental plots were similar initially. Before bower removal, the mean distance to the closest bower for both sets of plots ranged from $2.00 \mathrm{~m}$ to $2.56 \mathrm{~m}$ (table 2). Four bowers were added in the control plots during the experiment. These were in open areas in the arena, since their next-nearest neighbors were $2.7 \mathrm{~m}$ and $3.3 \mathrm{~m}$ away. Prior to leveling, only 7 bower pairs out of a total of 82 bowers in control and removal plots were closer than $1.6 \mathrm{~m}$.

Bowers were reestablished in the removal plots at the same density present in the controls. At the end of the study, mean distance between nearest bowers in the experimental plots ranged between $2.2 \mathrm{~m}$ and $2.7 \mathrm{~m}$ (mean, $2.5 \mathrm{~m}$; table 2). 
TABLE 1

Proportion of Males Occupying Bowers

\begin{tabular}{|c|c|c|c|}
\hline \multirow[b]{2}{*}{ DEPTH } & \multicolumn{3}{|c|}{ Bower Height above Average Substrate Level (cm) } \\
\hline & $\leq 8.0 \mathrm{~cm}$ & $8.1-15.0 \mathrm{~cm}$ & $\geq 15.1 \mathrm{~cm}$ \\
\hline \multicolumn{4}{|c|}{ MORNING COURTSHIP PERIOD } \\
\hline Shallow $(6 \mathrm{~m})$ & 1.00 & 0.88 & 1.00 \\
\hline$N$ & 3 & 16 & 25 \\
\hline Deep $(9 \mathrm{~m})$ & 0.91 & 1.00 & 1.00 \\
\hline$N$ & 11 & 18 & 9 \\
\hline \multicolumn{4}{|c|}{ AFTERNOON FEEDING PERIOD } \\
\hline Shallow $(6 \mathrm{~m})$ & 0.25 & 0.56 & 0.91 \\
\hline$N$ & 4 & 43 & 86 \\
\hline Deep $(9 \mathrm{~m})$ & 0.25 & 0.29 & 0.89 \\
\hline$N$ & 32 & 74 & 28 \\
\hline
\end{tabular}

Note. $-N$, Number of bowers observed at each depth in the control plots of the bower-removal experiment.

This mean distance was not significantly different from either initial conditions or controls $(P>0.05$; table 2$)$. Males established and abandoned 27 bowers on the experimental plots. The average distance to the nearest neighbor for the abandoned bowers was $1.4 \mathrm{~m}$. Of the 27 bowers that were abandoned, 15 (more than $50 \%$ ) were closer than $1.6 \mathrm{~m}$ to another bower. Additionally, the bowers abandoned on the experimental plots were usually the smallest bowers. None of the bowers in the tallest third of all bowers in a plot on a given day was ever abandoned. More than $50 \%$ of the bowers in the shortest third were eventually abandoned (table 3).

The mean size of bowers on shallow plots before the removal of bowers was $18.0 \mathrm{~cm}$ high, $83.8 \mathrm{~cm}$ in base diameter, and $28.9 \mathrm{~cm}$ in top diameter. Deep-water bowers were somewhat smaller: $14.2 \mathrm{~cm}$ high, $81.3 \mathrm{~cm}$ wide, and $34.0 \mathrm{~cm}$ in top diameter. The difference in heights was significant ( $t$-test, $P<0.01$ ), whereas the differences in top and base diameters were not. Bowers in the controls at the end of the experiment were the same size as those present at the beginning $(P>0.05)$.

New bowers on experimental removal plots increased in height at the rate of 1 $\mathrm{cm}$ per day (fig. 4). For the first 6 days, males in deep water and those in shallow water added to the bowers at the same rate. The average height of bowers in both groups on day 6 was $7 \mathrm{~cm}$; from day 7 , however, the sizes of shallow and deep bowers diverged. Males building bowers in shallower water made them higher and broader than those in deeper water ( $t$-test, $P<0.01$ ). After 15 days, shallow-water bowers averaged $14.8 \mathrm{~cm}$ in height, whereas the deeper-water bowers averaged $11.9 \mathrm{~cm}$ in height. Bowers in the shallow-water controls were $17.3 \mathrm{~cm}$ tall at this date; bowers in the deep-water controls were $14.0 \mathrm{~cm}$. After $2 \mathrm{wk}$, the mean height of the bowers on the experimental plots was still $2.5 \mathrm{~cm}$ less than the mean height on the control plots $(P>0.05)$.

At the end of 15 days, the average base width of the shallow-water bowers on the removal plots was $86.4 \mathrm{~cm}$, similar to the $88.9-\mathrm{cm}$ average base width of the 
TABLE 2

Mean Distance between Bowers

\begin{tabular}{|c|c|c|c|c|}
\hline & \multicolumn{2}{|c|}{ All Bowers (m) } & \multicolumn{2}{|c|}{$\begin{array}{l}\text { Bowers Established duRING } \\
\text { ObSERVATION Period }\end{array}$} \\
\hline & Initial & Final & Successful & Unsuccessful \\
\hline \multicolumn{5}{|l|}{ Control Plots } \\
\hline Shallow 1 & 2.30 & 2.41 & 2.72 & 0 \\
\hline SD & 0.47 & 0.45 & 0.18 & \\
\hline$N$ & 9 & 11 & 2 & \\
\hline Shallow 3 & 2.00 & 2.00 & 0 & 0 \\
\hline SD & 0.51 & 0.51 & & \\
\hline$N$ & 17 & 17 & & \\
\hline Deep 1 & 2.47 & 2.62 & 3.35 & 0 \\
\hline SD & 0.51 & 0.71 & 1.36 & \\
\hline$N$ & 10 & 12 & 2 & \\
\hline Deep 3 & 2.34 & 2.34 & 0 & 0 \\
\hline $\mathrm{SD}$ & 0.63 & 0.63 & & \\
\hline$N$ & 12 & 12 & & \\
\hline \multicolumn{5}{|c|}{ Removal Plots } \\
\hline Shallow 2 & 2.56 & 2.20 & 0 & 1.56 \\
\hline SD & 0.60 & 0.78 & & 0.45 \\
\hline$N$ & 11 & 13 & & 12 \\
\hline Shallow 4 & 2.48 & 2.67 & 0 & 1.58 \\
\hline SD & 1.15 & 0.84 & & - \\
\hline$N$ & 10 & 7 & & 1 \\
\hline Deep 2 & 2.53 & 2.65 & 0 & 0.82 \\
\hline $\mathrm{SD}$ & 0.60 & 0.25 & & 0.48 \\
\hline$N$ & 14 & 10 & & 4 \\
\hline Deep 4 & 2.21 & 2.41 & 0 & 1.61 \\
\hline SD & 0.70 & 0.18 & & 0.75 \\
\hline$N$ & 12 & 10 & & 10 \\
\hline
\end{tabular}

Note.-Distances were measured from the center of one bower to the center of the nearest bower for control and manipulated plots. Shallow plots were at a water depth of 6-8 m. Successful bowers appeared on the control plots during the experimental period and remained at the end of the experiment, 16 days later. Unsuccessful bowers appeared and then disappeared during the experimental period.

TABLE 3

Number of Males Remaining Above and Abandoning Bowers of Different Sizes

\begin{tabular}{ccc}
\hline \hline Relative Bower Height & Remaining & Abandoning \\
\hline Tallest third & 42 & 0 \\
Middle third & 37 & 5 \\
Shortest third & 21 & 22 \\
TOTAL & 100 & 27 \\
\hline
\end{tabular}

NoTE. $-\chi^{2}=35.0, P<0.01$. 


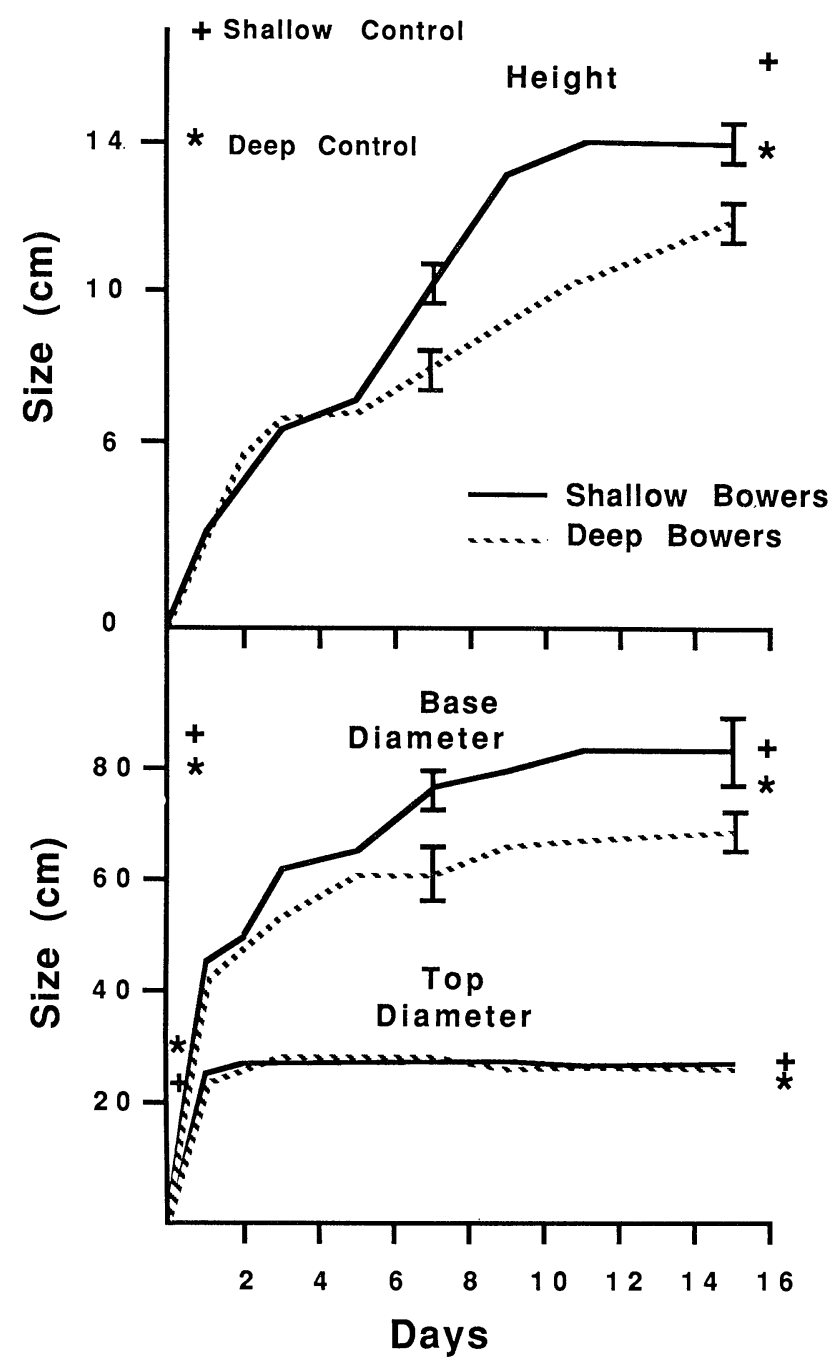

Fig. 4.-Growth rate of bowers after experimental removal of existing bowers. Mean controls taken at both the beginning and the end of the experiment: + , shallow water; *, deep water. Error bar indicates $95 \%$ confidence interval.

shallow controls. However, at the same time, the width of the base of the experimental bowers in deep water, $71.1 \mathrm{~cm}$, was significantly smaller than that of the experimental bowers in shallow water $(t$-test, $P<0.01)$. Top diameter, which appears to be species-specific (McKaye 1983), was the same on all plots within 2 days (fig. 4).

\section{Temporal and Depth Distribution of Bowers}

Bowers are normally distributed from 1.5- to 15.0-m water depth (fig. 5), with a peak at $7.5 \mathrm{~m}$. However, in the dry season, during August and September, when 


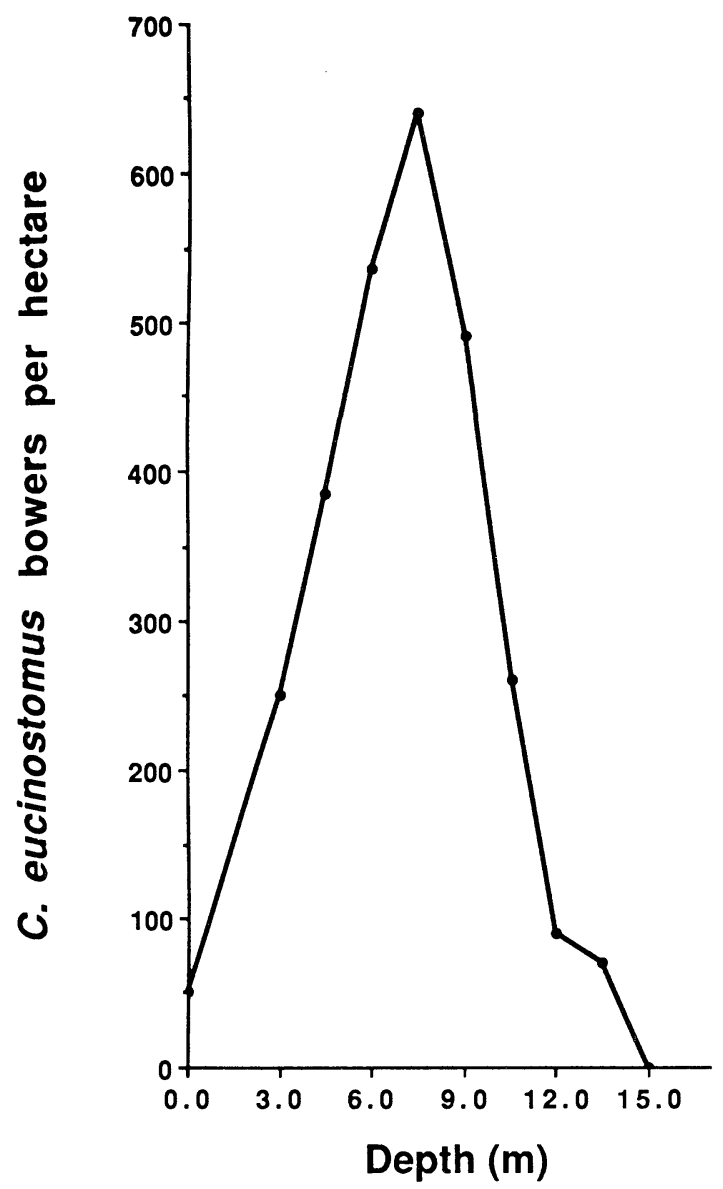

FIG. 5.-Density of male bowers versus water depth, averaged over the calendar year.

the Lake is still near its seasonally high levels (Eccles 1984), more bowers are found at shallow depths $(1.5-6.0 \mathrm{~m})$. The distribution of bowers is significantly shallower in the dry season than in the wet season, during January and February (Wilcoxon test, paired transects at same location along the beach, $P<0.01$; fig. 6). At Cape Maclear, the breeding season for Cyrtocara eucinostomus had two distinct peaks: July-September and January-April (fig. 7).

At night, $C$. eucinostomus cichlids moved into shallow water, with approximately $66 \%$ of the population located between 6 and $8 \mathrm{~m}$. Only $13 \%$ of $C$. eucinostomus individuals were found between 9 and $11 \mathrm{~m}$ in depth (table 4).

Consistency of courtship pattern in arena.-When the data were partitioned by depth, there were no significant differences between deep-water and shallowwater bowers in the mean number of females entering or circling (table 5). Therefore, the increased density of bowers at 6.0-7.5 $\mathrm{m}$ (fig. 6) does not appear to be driven by female choice of males at that depth. 


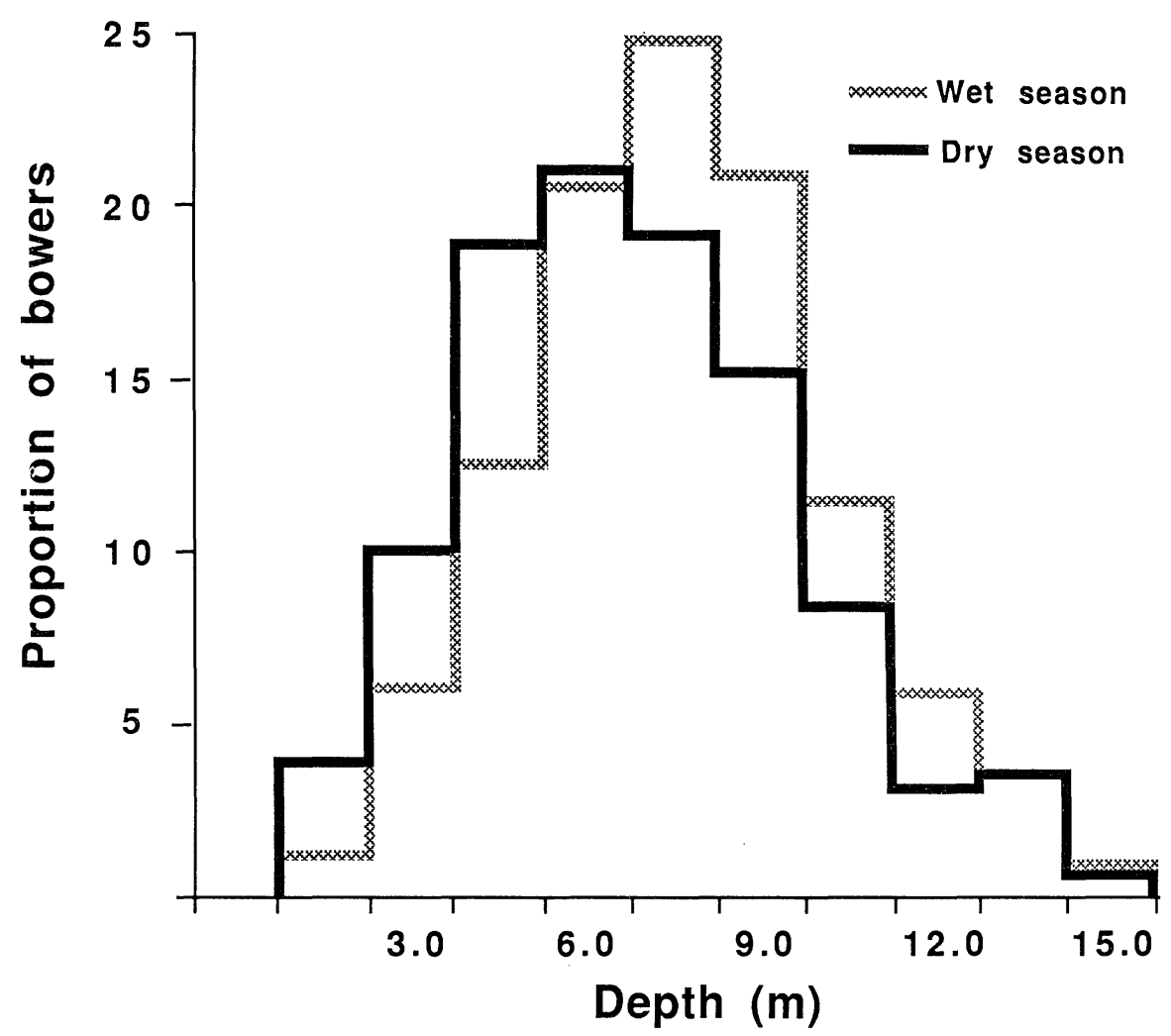

Fig. 6.-Proportion of male bowers versus water depth at the peak of breeding in the dry season (August-September) and at the peak of breeding in the wet season (JanuaryFebruary).

\section{DISCUSSION}

Male behavior patterns that are "expensive" in both time and energy often predominate in lekking species (Bradbury 1981; Bradbury and Gibson 1983; Höglund and Lundberg 1987). The continual movement of sand in bower construction is a behavior typical of Cyrtocara eucinostomus males. They deposit a mouthful of sand on the bower every 15 seconds, on the average (McKaye 1983). This activity is the primary behavior of males during the morning courtship period (McKaye 1983). Why do these relatively small fish expend so much time and energy in building "sand castles" (Bass 1988) with base diameters more than eight times their own standard length (McKaye 1983, fig. 1)? Could sand movement and bower size have been subject to "runaway" selection (Fisher 1930) in which females select males that display above the largest bowers?

In our observations of two males with adjacent bowers of contrasting sizes, females entered the taller bower 2.5 times as often as the smaller bower. They also circled with males above the larger bower 3 times as often as with males above the 


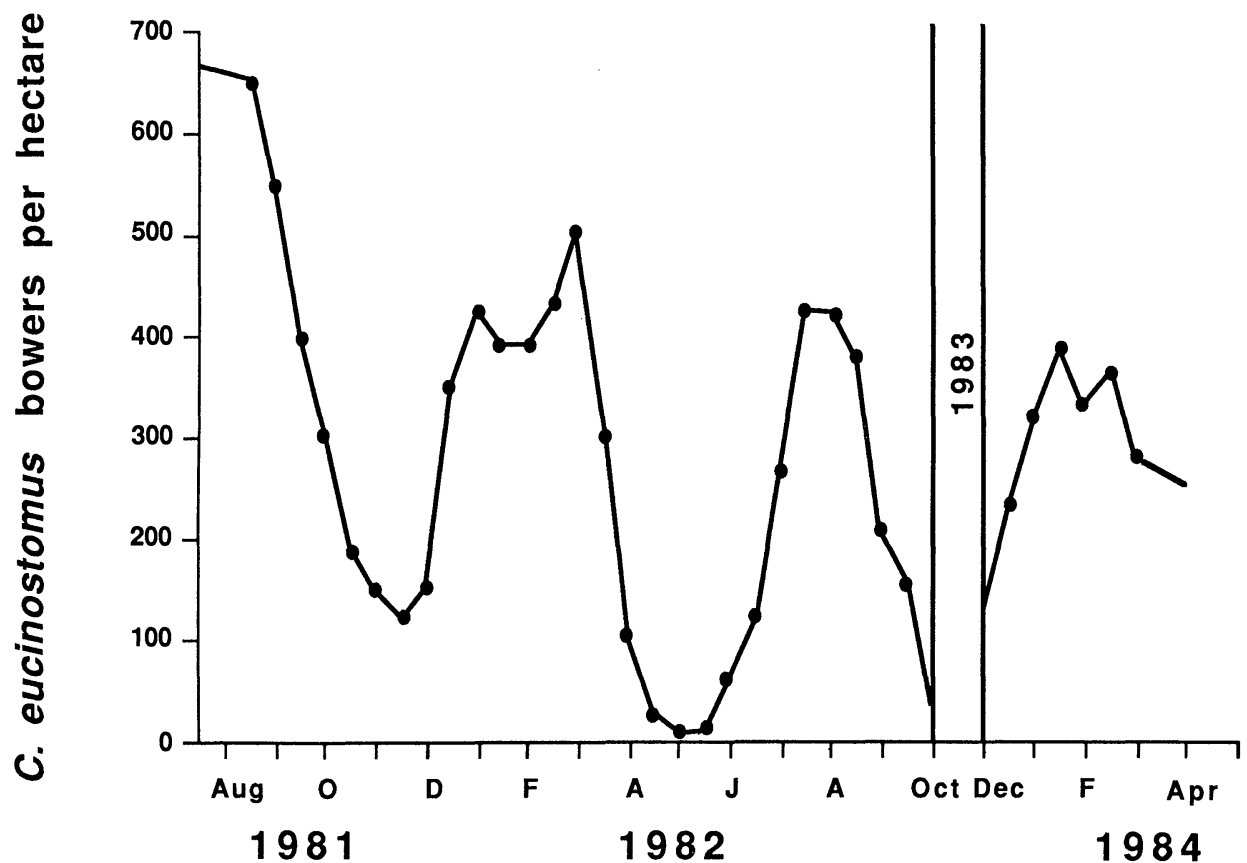

FIG. 7.-Breeding seasonality of Cyrtocara eucinostomus. No transects were made from November 1982 to November 1983.

TABLE 4

Nocturnal Distribution of Cyrtocara EUCINOSTOMUS

\begin{tabular}{crc}
\hline \hline Depth $(\mathrm{m})$ & $N$ & Fish $/ 25 \mathrm{~m}^{2}$ \\
\hline $3-5.9$ & 8 & $11.8 \pm 2.3$ \\
$6-8.9$ & 12 & $42.9 \pm 14.3$ \\
$9-11.9$ & 12 & $8.6 \pm 4.1$ \\
$12-14$ & 8 & $2.1 \pm 1.2$ \\
\hline
\end{tabular}

Note. $-N$, Number of $25-\mathrm{m}^{2}$ transects. Values are mean numbers of fish \pm one standard error.

smaller bower (fig. 2). Males with taller bowers expended more time and energy in defending the bower from other breeding males. They also spent more time and energy defending the bower territory against nonbreeding colored conspecifics, including "sneakers" (McKaye 1983). This difference in aggression was not generalized to other species of fish, however. There were no statistical differences (Wilcoxon test, $P>0.05$ ) among males above tall and short bowers in attacks on heterospecific fishes (fig. 3).

We suggest that females were attracted to the larger bower from a distance, increasing the probability that the male will engage in courtship behavior. The relationship between courting females and attacks on breeding conspecific males 
TABLE 5

Female Behavior in Response to Height of Bower along the Depth Gradient at Cape Maclear, Lake Malawi

\begin{tabular}{lccc}
\hline \hline Water Depth & $N$ & $\begin{array}{c}\text { Short } \\
\text { Bowers }\end{array}$ & $\begin{array}{c}\text { Tall } \\
\text { Bowers }\end{array}$ \\
\hline \multicolumn{4}{c}{ MEAN NUMBER OF FEMALES ENTERING BOWER PER IO MIN } \\
Shallow (6-8 m) & 34 & 0.3 & 0.8 \\
Deep (>8 m) & 52 & 0.5 & 1.1 \\
MEAN NUMBER OF FEMALES CIRCLING ABOVE BOWER PER IO MIN \\
Shallow (6-8 m) & 34 & 0.1 & 0.4 \\
Deep ( $>8 \mathrm{~m})$ & 52 & 0.2 & 0.3 \\
\hline
\end{tabular}

NoTE.-No significant differences between responses to shallow and deep bowers were found $(N$, number of 10 -min observation periods; two-way ANOVA, $P>0.05)$. Differences between short and tall bowers were significant at both depths $(P<0.01)$.

by the males above the paired bowers supports this interpretation. The presence of a female is required to initiate courtship by the male, and our data suggest that the height of the bower is a primary component of the characteristics that attract females to a bower and a mate.

Until artificial bowers can be constructed and tests of the effect of malecourtship variance conducted, the contribution of other factors in female choice cannot be assessed. For example, the quality of a male's courtship display and his ability to defend the bower from egg eaters specialized to steal eggs before the female can put them into her mouth (McKaye 1984) probably play a role in inducing the female to lay eggs with a given male.

Other independent data on bower location and abandonment support the view that bower height is important to male reproductive success. During the course of the study, bowers were abandoned. If bower size is not critical to attracting females, bower abandonment should be random in relation to size. This was not the case. All of the tallest bowers remained occupied throughout the entire study period. Of the smallest bowers, more than half were abandoned (table 3 ). This result parallels the finding for the satin bowerbird (Ptilonorhynchus violaceus) that the bowers destroyed most often were those of "lower-than-average quality" (Borgia 1985).

Furthermore, we found a nonrandom pattern of bower occupancy in the afternoon, when most males leave the arena to feed (McKaye 1983). More than $90 \%$ of the largest bowers $(>15.1 \mathrm{~cm})$ continued to be occupied, but males remained above only $25 \%$ of the bowers shorter than $8.0 \mathrm{~cm}$. These observations suggest a trade-off between energy expenditure and breeding success: a male above a large bower forgoes foraging during the day, whereas a male on a smaller, unattractive bower gains energetically by foraging with increased efficiency in the open, deeper waters of Lake Malawi, where zooplankton densities are greater than in the vicinity of the arena (McKaye 1983; McKaye et al. 1985).

We aiso considered the hypothesis that location in the arena is important in female choice, with males at deeper sites being less attractive to females. Hence, 
female choice might also explain the increased density of males at $7.5 \mathrm{~m}$ (fig. 6). However, the only factor in female choice that varied significantly was the size of the bower, and no difference in female selection based on depth was apparent (table 5).

Therefore, we rejected the hypothesis that female choice is responsible for lek structure, and we examined other possible ecological processes. If depth and light penetration are not important in female choice, why is the distribution of males not uniform within the acceptable breeding range of this species? Nocturnal predation appears to be responsible for the crowding of this species into shallow water (McKaye 1983). Fish at the deeper limits of the arena are more susceptible to catfish predation. Nevertheless, a deep, large bower does appear to be attractive to females, and the risk of staying with such a bower may be counterbalanced by the increased reproductive opportunities.

This cost-benefit hypothesis predicts that, at night, C. eucinostomus fish would shift into shallower water. Accordingly, we examined nocturnal distribution and found C. eucinostomus individuals concentrated at depths between 6 and $8 \mathrm{~m}$ at a density 20 times that found at depths between 12 and $14 \mathrm{~m}$ (table 4). The diurnal depth-distribution pattern for bower occupation is similar, except that the difference between the number of bowers at 6-8-m depth and those at 12-14-m depth is only tenfold. Thus, the fish crowd into the $6-$ to $8-\mathrm{m}$ depth range at night at a density twice that expected from the diurnal pattern.

We also found a difference in bower abandonment correlated with depth. This might explain the origin of some of the "extra" fish in the shallower water. Bowers between 8.1 and $15.0 \mathrm{~cm}$ high in the deeper control plots were twice as likely to be abandoned in the late afternoon as were those in the shallow depths. This was the size at which the growth of deep bowers slowed relative to that of shallow bowers (fig. 4). Of the shallow-water bowers, $78 \%$ were occupied in the late afternoon, as opposed to only $40 \%$ of the deep bowers. This abandonment in the afternoon was probably the reason for the slower growth and the consistently smaller size of bowers below $10 \mathrm{~m}$ in depth. In the morning, no difference in occupancy rate existed: all bowers were occupied.

The bower-removal experiment also provided data demonstrating the importance to this species of traits associated with bower size. By the morning following removal, the top diameter, or "courtship platform," was not significantly different from the average control size of $29 \mathrm{~cm}$ in diameter. This is the same courtshipplatform diameter found in 1978 and at Nkhata Bay (McKaye 1983). Bowers were rapidly rebuilt and, in $2 \mathrm{wk}$, were almost the size of controls.

The removal experiments suggest that a consistent spacing mechanism operates within this arena, allowing the arena density to recover rapidly from a disturbance. Nevertheless, if bowers are removed, they are not rebuilt at the exact site of the former bower. The resilience of this arena is biologically important. Storms with large waves $(>3 \mathrm{~m})$ often arise, primarily in the wet season, and they can level the shallowest bowers in a few hours; as soon as the storm subsides, the bower can be reestablished. It appears that the shallow limits of the arena are primarily determined by both abiotic factors (wave action) and biotic factors (e.g., bird predation; McKaye 1983) and not by female choice. 
Our results suggest that, within this species, a specific characteristic, bower size, influences the mate preference of females and that males evolve behaviors that tend to increase the size of their bower. Yet, in some other Malawi lekking species, the bower is nothing more than a shallow depression in the sand. Since ten different major bower forms have evolved in Lake Malawi (McKaye 1984, in press; McKaye and Stauffer 1988), no bower form seems ideally adapted for reducing egg predation after a female lays her eggs and before she takes them into her mouth. Hence, we suggest that bower form evolves over time, responding primarily to female choice.

This field study shows that two conditions are necessary for sexual selection to operate among cichlids: (1) variation in a characteristic, bower size, acquired through two male behavioral traits, sand movement and aggression, and (2) female use of this characteristic as a criterion in mating. To further test the sexualselection hypothesis of mate choice and cichlid speciation (Dominey 1984), the heritability of bower building and defense must be examined. Nevertheless, underwater exploration within Lake Malawi supports the assertion that lekbreeding species should exhibit "extraordinary geographic variation in male attributes" (Arnold 1983, p. 86). On the eastern side of the Nankumba peninsula, we have recently discovered two cichlid populations, or perhaps species, that are morphologically similar to C. eucinostomus on the western side of the Nankumba peninsula. One of these entities breeds at a smaller size and has bowers shorter than $1 \mathrm{~cm}$ in $15 \mathrm{~m}$ of water; the other has bowers taller than $35 \mathrm{~cm}$ in $4.5 \mathrm{~m}$ of water. The intriguing questions of whether these differences could have arisen from differences in female mate preference and caused the splitting of these species is now the subject of further investigation (T. J. Lovullo, McKaye, and Stauffer, MS).

\section{SUMMARY}

The hypothesis that male reproductive success of a lekking species depends on the size of the display site was investigated. For the species Cyrtocara eucinostomus, the height of the bower appears to be a crucial characteristic used by females in determining with which males to court and eventually spawn. In this study, males more vigorously defended, and were less likely to abandon, taller bowers. This pattern was consistent at all depths, although the species showed a peak density of bowers at $6.0-7.5 \mathrm{~m}$ in depth. The lower-depth distribution of bowers is probably due to nocturnal predation by deep-dwelling catfish, and the upper-depth distribution depends on wave action eroding the bowers. Therefore, the pattern of bower distribution appears to be influenced by ecological processes.

When bowers were experimentally removed, new bowers were built immediately, but not at exactly the same spot. The top diameter of the bower was reestablished in one day. These bower characteristics were specific for this species. The new bowers grew at a rate of approximately $1 \mathrm{~cm}$ per day and reached the heights of control bowers in approximately two weeks. C. eucinostomus bred year-round but with a distinct breeding peak in both the wet and the dry seasons. During these periods, the density of bowers at $6.0-7.5 \mathrm{~m}$ appeared 
saturated, with a distance of approximately $2.5 \mathrm{~m}$ between the centers of the nearest neighbors' territories.

\section{ACKNOWLEDGMENTS}

We are grateful to J. E. Gates, L. M. Graceffa, J. Hoogland, J. Howard, R. Morgan, F. Rohwer, M. A. Schlessman, and three anonymous reviewers for their comments on the manuscript, and to B. McKaye and S. Rohwer for producing the figures. Field assistance and permits from the Malawi Fisheries and Parks departments made the entire study in Lake Malawi National Park possible. The Department of Animal Sciences, Bunda College of Agriculture, University of Malawi, provided valuable logistic support in the latter portions of this study, which was made possible by a cooperative agreement between the universities of Malawi and Maryland. The work was supported by National Science Foundation grants BSR 82-14603 (K.R.M.) and BNS 86-06836 (K.R.M., J.R.S.). Contribution 2027-AEL, University of Maryland, Center for Environmental and Estuarine Studies.

\section{LITERATURE CITED}

Arnold, S. J. 1983. Sexual selection: the interface of theory and empiricism. Pages 67-108 in P. Bateson, ed. Mate choice. Cambridge University Press, Cambridge.

Bass, T. A. 1988. This African lake turns out to be a fine kettle of fish. Smithsonian 19:144-155.

Borgia, G. 1985. Bower quality, number of decorations and mating success of male satin bowerbirds (Ptilonorhynchus violaceus): an experimental analysis. Anim. Behav. 33:266-271.

Borgia, G., S. G. Pruett-Jones, and M. A. Pruett-Jones. 1985. The evolution of bower-building and the assessment of male quality. Z. Tierpsychol. 76:225-236.

Bradbury, J. W. 1981. The evolution of leks. Pages 138-169 in R. D. Alexander and D. W. Tinkle, eds. Natural selection and social behavior: recent research and new theory. Chiron, New York.

Bradbury, J. W., and R. M. Gibson. 1983. Leks and mate choice. Pages 109-140 in P. Bateson, ed. Mate choice. Cambridge University Press, Cambridge.

Collias, N. E., and E. C. Collias. 1983. Nest building and bird behavior. Princeton University Press, Princeton, N.J.

Darwin, C. 1871. The descent of man and selection in relation to sex. J. Murray, London.

Dominey, W. C. 1984. Species flocks in Hawaiian Drosophila and the cichlid fishes of the Great Lakes of Africa: consequences of sexual selection and life history phenomena. Pages 231-249 in A. A. Echelle and I. Kornfield, eds. Evolution of fish species flocks. University of Maine at Orono Press, Orono.

Eccles, D. H. 1984. On the recent high levels of Lake Malawi. S. Afr. J. Sci. 80:461-468.

Fisher, R. A. 1930. The genetical theory of natural selection. Dover, New York.

Fryer, G., and T. D. Iles. 1972. The cichlid fishes of the Great Lakes of Africa: their biology and evolution. Oliver \& Boyd, London.

Höglund, J., and A. Lundberg. 1987. Sexual selection in a monomorphic lek-breeding bird: correlates of male mating success in the great snipe Gallinago media. Behav. Ecol. Sociobiol. 21: 211-216.

Keenleyside, M. H. A. 1979. Diversity and adaptation in fish behaviour. Springer-Verlag, New York. Lande, R. 1981. Models of speciation by sexual selection on polygenic traits. Proc. Natl. Acad. Sci. USA 78:3721-3725.

Lowe-McConnell, R. H. 1959. Breeding behaviour patterns and ecological differences between Tilapia species and their significance for evolution within the genus Tilapia (Pisces: Cichlidae). Proc. Zool. Soc. Lond. 132:1-30.

McKaye, K. R. 1983. Ecology and breeding behavior of a cichlid fish, Cyrtocara eucinostomus, on a large lek in Lake Malawi, Africa. Environ. Biol. Fishes 8:81-96. 
1984. Behavioural aspects of cichlid reproductive strategies: patterns of territoriality and brood defence in Central American substratum spawners versus African mouth brooders. Pages 245-273 in R. J. Wootton and C. W. Potts, eds. Fish reproduction: strategies and tactics. Academic Press, London.

1986. Mate choice and size assortative pairing by the cichlid fishes of Lake Jiloa, Nicaragua. J. Fish Biol. 29 (Suppl. A):135-150.

- In press. Sexual selection and the evolution of the cichlid fishes of Lake Malawi, Africa. In M. H. A. Keenleyside, ed. Cichlid fishes: behaviour, ecology and evolution. Chapman \& Hall, London.

McKaye, K. R., and W. N. Gray. 1984. Extrinsic barriers to gene flow in rock-dwelling cichlids of Lake Malawi: macrohabitat heterogeneity and reef colonization. Pages 169-184 in A. A. Echelle and I. Kornfield, eds. Evolution of fish species flocks. University of Maine at Orono Press, Orono.

McKaye, K. R., and J. R. Stauffer, Jr. 1988. Seasonality, depth and habitat distribution of breeding males of Oreochromis spp. 'Chambo' in Lake Malawi National Park. J. Fish Biol. 33: $825-834$.

McKaye, K. R., R. D. Makwinja, W. W. Menyani, and O. K. Mhone. 1985. On the possible introduction of non-indigenous zooplankton-feeding fishes into Lake Malawi, Africa. Biol. Conserv. 33:389-407.

Neil, S. J. 1984. Field studies of the behavioral ecology and agonistic behavior of Cichlasoma meeki (Pisces: Cichlidae). Environ. Biol. Fishes 10:59-68.

Perrone, M., Jr. 1978. Mate size and breeding success in a monogamous cichlid fish. Environ. Biol. Fishes 3:193-201. 